\title{
Modelling the impact of performance management practices on firm performance:
}

\section{Interaction with human resource management practices}

\author{
Andrey Pavlov \\ School of Management, Cranfield University, Cranfield, Bedfordshire MK430AL, UK \\ T: +44 (0)1234 751122; E: andrey.pavlov@cranfield.ac.uk \\ Matteo Mura \\ Department of Management, University of Bologna, Via Terracini 28, 40131, Bologna, Italy \\ T: +39051 2090212; E: matteo.mura@unibo.it
Monica Franco-Santos
School of Management, Cranfield University, Cranfield, Bedfordshire MK430AL, UK T: +44 (0)1234 751122; E: monica.franco@cranfield.ac.uk \\ Mike Bourne* \\ School of Management, Cranfield University, Cranfield, Bedfordshire MK430AL, UK \\ T: +44 (0)1234 754514; E: m.bourne@cranfield.ac.uk
}

* Corresponding author 


\title{
Modelling the impact of performance management practices on firm performance: Interaction with human resource management practices
}

\begin{abstract}
The paper draws on resource orchestration theory to investigate whether and how performance management $(\mathrm{PM})$ practices interact with human resource management (HRM) practices in organizations as well as how this interaction affects firm performance. The proposed theoretical model was tested through a survey of 192 UK firms using Partial Least Squares approach for structural equations modelling. The findings show that the effect of PM practices on firm performance is better explained when the interaction between these practices and other organizational practices is considered. In particular, we examine the extent to which the interaction between PM practices and commitment-based HRM practices affects performance. We find that when HRM practices and PM practices are misaligned, their effect on performance can be negative. This is the first paper in the PM literature that establishes the relationship between PM and HRM practices in organizations and demonstrates the effect of this relationship on firm performance.
\end{abstract}

Keywords: performance management; performance measurement; human resource management; survey; partial least squares. 


\section{Introduction}

This paper responds to an increasing number of calls in the operations management (OM), and more specifically, performance management (PM) literature for understanding the role of human resource management (HRM) in the task of managing firm performance (e.g., Leffakis and Dwyer 2014) and for incorporating it into the existing models of the effects of PM systems on performance (e.g., Bourne et al. 2013; Busby and Williamson 2000; Vagneur and Peiperl 2000; de Toni and Tonchia 2001). Research in PM has seen a number of attempts to observe (Askim 2004), conceptualize (Pavlov and Bourne 2011) and quantify (Davis and Albright 2004) the effects of PM on performance. However, as the discussions in the field moved from the design and evaluation of PM frameworks to the issues of implementation, maintenance, and collaborative use (Bourne 2005; Folan and Browne 2005), it became apparent that the relationship between PM and firm performance was more complex than previously thought (Franco-Santos et al. 2012).

The effect of PM practices on firm performance is difficult to untangle because PM practices do not operate in isolation (De Toni and Tonchia 2001). PM practices interact with multiple organizational practices. They share 'inputs' with other practices (e.g., goal selection, data collection) and produce 'outputs' for other practices (e.g. performance information) (Kaydos 1999). Specifically, the relationship between PM practices and HRM practices is likely to be of high significance as outputs of PM practices are more often than not used by managers to influence and guide personnel decisions (Schuler et al. 1991). For example, it is now common for firms to cascade down organizational performance measures to the individual level and make individual rewards and training needs, which are both considered to be HRM practices, contingent on the achievement of specific performance results. 
To date the PM literature has been silent about how or why PM practices interact with HRM practices and whether these interactions are likely to influence firm performance. Drawing on the ideas of resource orchestration theory (Sirmon et al. 2007, 2011) as well as previous HRM research suggesting that HRM practices influence performance through their influence on the social structure of the firm (e.g., Chadwick et al. 2015; Collins and Smith 2006), we address this gap in our knowledge arguing that managers combine these practices as they believe that together these practices help them to better organize, synchronize and support -i.e., 'orchestrate'- their human resources, improving the firm's social capital and overall performance.

Heeding these considerations, we set the task of not simply testing the presence of the separate effects of PM and HRM practices on firm performance, but also of conceptualizing and measuring their interaction testing its combined impact on firm performance. In other words, we hypothesized that, although we would see independent effects of PM and HRM on firm performance, we would also be able to distinguish and assess the effect of their interaction. This in turn would allow us to show empirically the importance of analyzing PM effects in conjunction with HRM practices, as the literature above intimated.

More formally, our research was guided by the following research questions:

a) Do PM practices and HRM practices have an effect on firm performance in their own right?

b) Does the interaction of PM practices and HRM practices have an effect on firm performance?

Following a review of the relevant literature, these research questions were translated into five hypotheses, which were subsequently tested by means of a mailed survey and analyzed using a structural equation modeling approach. The results show that both PM practices and HRM practices influence firm performance, although several of these effects are indirect. More interestingly, our 
results show that firm performance is affected by the interaction between PM practices and two key HRM practices (recruitment and reward practices), thus demonstrating that PM initiatives do indeed rely on the support of HRM practices for generating organizational performance.

The rest of the paper is structured in the following way. The next section develops and refines the argument into a set of formal hypotheses. The subsequent section operationalizes the key constructs and describes our approach to data collection and analysis. This is followed by the summary of our findings and a detailed discussion of the effects we observed. The paper closes with a brief conclusion, revisiting our findings in light of the recent research in PM and outlining several avenues for further research.

\section{Literature review and hypothesis development}

\subsection{PM practices and firm performance}

PM practices have been described as the formal practices "by which the company manages its performance in line with its corporate and functional strategies and objectives" (Bititci et al. 1997, 524). Such practices mainly include the selection of strategic goals, the use of performance measures and targets, as well as the periodic review and evaluation of measured performance (Buckingham and Coffman 1999; Ferreira and Otley 2009; Otley 1999; Bititci et al. 1997; Lebas et al. 1995). These practices are used for communicating direction, providing feedback on current performance, influencing behaviour and stimulating improvement action (Bourne and Bourne 2011). In this sense, PM practices closely parallel what Bititci et al. (2011) call "managerial processes". The latter, however, are a broad and generic set, while PM practices have performance improvement as their distinct aim. 
The link between PM practices and firm performance has been widely debated over the last decades (De Geuser et al. 2009; Evans 2004; Hoque 2004; Van der Stede et al. 2006; Hoque and James 2000). Studies examining the direct relationship between PM practices and firm financial performance have produced inconclusive and sometimes contradictory results, with some work providing evidence of a positive effect of PM on financial performance (Davis and Albright 2004; DeBusk and Crabtree 2006; Ittner and Larcker 1998), and other suggesting the opposite (Braam and Nijssen 2004; Griffith and Neely 2009; Ittner et al. 2003).

Some scholars suggest that PM practices contribute to firm financial performance but they do so indirectly. For instance, PM practices have been found to affect performance through their effects on critical organizational areas such as team goal achievement (Scott and Tiessen 1999), project delivery (Davila 2000), customer satisfaction (Hyvonen 2007), and managerial results (Hall 2008). PM practices have also been shown to contribute to performance by stimulating decision-making and continuous improvement (Nudurupati and Bititci 2005), generating strategic alignment (Chenhall 2005) and organizational learning and innovation (Henri 2008). These firm capabilities are likely to translate into higher levels of company non-financial performance in terms of quality of products and services offered, delivery time, flexibility in volume and product mix, and customer satisfaction (Chenhall 2005; Malina and Selto 2001; De Leeuw and van den Berg 2011), which in turn are likely to lead to higher firm financial performance.

The specific underlying mechanisms that explain why PM practices influence firm performance have not always been explicit in the literature (Franco-Santos et al. 2012). However, drawing on resource orchestration theory (Sirmon et al. 2007, 2011), the recent work of Koufteros et al. (2014) is starting to shed some light on this issue. Koufteros et al. (2014) suggest that PM practices influence firm performance because they provide managers with the information they require to take action and 
organise their work and the firm resources to meet strategic demands. Managers at all levels must coordinate and organise themselves and the strategic resources at their disposal to improve the competitive advantage of their firm (Sirmon et al., 2011). PM practices facilitate the coordination of managerial action and help firms to structure, bundle and leverage their resources, orienting employees towards achieving firms' goals and objectives (Koufteros et al. 2014; Chadwick et al. 2015).

We thus expect that PM practices will positively affect firm performance. However, considering the evidence and theoretical underpinnings presented above, the direct effect may be more readily observable when firm performance is understood as non-financial performance, which is more likely to be influenced by managers' decisions and actions:

Hypothesis H1: PM practices positively affect firm non-financial performance.

\subsection{Commitment-based HRM practices and firm performance}

The role of HRM in generating firm performance is well-recognised among firms in all sectors (Wright et al. 2003). HRM practices have been classified into transaction-based and commitmentbased practices (Arthur 1992). Commitment-based HRM practices emphasise mutual employeeemployer relationships focused on long-term exchange, while transaction-based HRM practices emphasise individual short-term exchange employee-employer relationships. Recent reviews of the field of HRM suggest that commitment-based practices are more likely to lead to higher firm performance, as these practices create an environment conducive to higher productivity; in contrast, transactional-based practices are perceived to limit the potential of HRM as a driving force behind firm performance (Arthur 1992; Batt 2002; Collins and Smith 2006; Huselid et al. 1997; McClean and Collins, 2011; Youndt et al. 1996). Based on the work of Arthur (1992) and Tsui et al. (1997), 
Collins and Smith $(2006,544)$ suggest that "the exact individual HRM practices that create a commitment-based environment differ across companies and studies, but they generally include a combination of employee selection practices that focus on creating internal labor markets and assessing fit to the company rather than on specific job requirements; compensation practices that focus employee motivation on group and organizational performance indicators; and training programs and performance appraisals that emphasize long-term growth, team building, and the development of firm-specific knowledge".

Drawing on resource orchestration theory (Sirmon et al. 2007, 2011), HRM scholars argue that commitment-based HRM practices become critical for firms "by increasing the knowledge, skills, and abilities of employees, by increasing their motivation, and by organizing work to give employees the best opportunity to help further the accomplishment of their firms' goals" (Chadwick et al. 2015, p. 362). In other words, commitment-based HRM practices help managers to orchestrate the firm's human resources in a way that builds the support for the firm's competitive position (Chadwick et al. 2013, 2015). Commitment-based HRM practices thus favour long-term investments in human resources, whose immediate payoff affects non-financial performance before it is reflected in financial performance indicators. Consequently, based on these ideas, we expect to find that the use of commitment-based HRM practices will be related to firm performance, in particular, the nonfinancial dimensions of performance. We thus propose the following hypotheses:

Hypothesis H2: Commitment-based HRM practices positively affect firm non-financial performance.

Specifically:

Hypothesis H2a: Commitment-based recruitment practices positively affect firm nonfinancial performance. 


\section{Hypothesis H2b: Commitment-based reward practices positively affect firm non-financial}

performance.

Hypothesis H2c: Commitment-based training practices positively affect firm non-financial performance.

Although commitment-based HRM practices have been argued to influence organisational performance, HRM researchers have pointed out that this relationship is underpinned by a number of intermediate mechanisms, whose nature and dynamics are worth investigating in order to better understand how HRM affects performance. In particular, researchers have argued that commitmentbased HRM practices affect performance through their influence on the organization's social climate for trust, cooperation and opportunity to share knowledge (Bowen and Ostroff 2004; Collins and Clark 2003; Collins and Smith, 2006). In fact, Collins and Smith (2006) have shown that the only way commitment-based HRM practices affect performance is through the mediation effect of social climate, implying that it is critical for this construct to be considered in research investigating the relationship between commitment-based HRM practices and performance.

Following Ashkanasy et al. (2000) and Smith et al. (2005), Collins and Smith (2006) define social climate as "the collective set of norms, values, and beliefs that express employees' views of how they interact with one another while carrying out tasks for their firm" (p. 547). By focusing employees' motivation on organizational rather than individual outcomes and by stimulating teamwork and longterm growth rather than short-term performance, commitment-based HRM practices are likely to contribute to an organisational social climate that stimulates employees' cooperation, trust, and opportunity to share knowledge. These elements motivate individuals to act in the best interest of the organisation, rather than in their own interest (e.g. Collins and Smith 2006; Rousseau 1995; Tsui et al. 1995). 
Organizational social climate is expected to be positively related to the firm's non-financial performance. This is supported by a number of reasons (Collins and Smith 2006). Firstly, a climate of cooperation limits competition between employees and increases their predisposition to share critical information with one another. This, in turn, positively affects firm performance by increasing the exchange of valuable and unique information. Similarly, a climate of commitment generates common understanding through which individuals with disparate experience, knowledge, and backgrounds can exchange and integrate new ideas. Finally, opportunity to share knowledge is widely seen as an essential aspect for increasing interaction and information exchange between individuals (Mayer et al. 1995; Nahapiet and Ghoshal 1998). Knowledge sharing helps an organization promote the exchange of valuable ideas between core knowledge workers that, in turn, will lead to greater innovation and firm growth.

Summarising the above discussion, organizational social climate would lead to a greater quality of products and services, and to a greater satisfaction of customers, it would also increase the innovation capability of the organization, and help the company to attract and retain essential employees. As these aspects contribute to the firm's non-financial performance, we expect that:

Hypothesis H3: The relationship between commitment-based HRM practices and nonfinancial performance is mediated by a firm's social climate for trust, cooperation and knowledge sharing.

Hypothesis H3a: The relationship between commitment-based recruitment practices and non-financial performance is mediated by a firm's social climate for trust, cooperation and knowledge sharing. 
Hypothesis H3b: The relationship between commitment-based reward practices and nonfinancial performance is mediated by a firm's social climate for trust, cooperation and knowledge sharing.

Hypothesis H3c: The relationship between commitment-based training practices and nonfinancial performance is mediated by a firm's social climate for trust, cooperation and knowledge sharing.

\subsection{Interaction between PM practices and HRM practices}

The crucial importance of HRM for effective PM and management control has been known for a very long time (Hofstede 1978). Research suggests that people management may be among the most significant factors contributing to the success of PM systems (Bourne et al. 2003, Kennerly and Neely 2003). The wider management literature has likewise highlighted that the type of HRM practices that organizations use are a key factor for the success of operations management and vice versa (Boudreau et al. 2003).

Resource orchestration theory (Sirmon et al. 2007, 2011) requires coordinated management of resources towards competitive advantage and therefore suggests that the interaction of PM and HRM practices would be critical for managers. This is because the alignment of these practices enables the managers better to synchronise their actions, thus improving the orchestration of resources and enhancing their firms' organizational capabilities and performance (Chadwick et al. 2015; Koufteros et al. 2014). PM practices provide managers with the information (e.g. goals, performance measurement results) to make "critical adjustments to their resources and mobilize requisite resources as conditions change" (Koufteros et al. 2014, p. 314). People are arguably firms' most important resource (Amabile and Kramer, 2011) so the ability of managers to use the information extracted 
from their PM practices to structure, bundle and leverage people's skills, knowledge and motivation through the firms HRM practices becomes crucial for firm success. Based on these arguments, we propose that:

Hypothesis H4: The interaction between PM practices and commitment-based HRM practices positively affects firm non-financial performance.

In particular:

Hypothesis H4a: The interaction between PM practices and commitment-based recruitment practices positively affects firm non-financial performance.

Hypothesis H4b: The interaction between PM practices and commitment-based reward practices positively affects firm non-financial performance.

Hypothesis H4c: The interaction between PM practices and commitment-based training practices positively affects firm non-financial performance.

\subsection{Firm non-financial and firm financial performance}

Non-financial performance has been shown to be a leading indicator of financial performance (Bititci et al. 2013, Ittner and Larcker 1998). This link between non-financial and financial performance is central to all contemporary performance measurement and management frameworks, from Balanced Scorecards (Kaplan and Norton 1992) to Strategy Maps (Kaplan and Norton 2000), to performance drivers (Olve et al. 1999) and the Performance Prism (Neely et al. 2002).

When discussing the link between non-financial and financial performance, both practitioners (e.g. Lingle and Schiemann 1996; Rucci et al. 1998) and scholars (e.g. Johnston and Michel 2008) emphasise three key non-financial performance dimensions, which are likely to influence the financial performance of a firm. These are: the attraction and retention of people with the attitudes, 
capabilities and behaviour that suit the mission and goals of the firm; the development of good quality products or services; and the satisfaction of customer expectations. Firstly, being able to hire from the best pool of potential employees is critical for an organization as this helps to improve the quality of its workforce and facilitates the delivery of its mission and the achievement of its goals. In addition, having attracted and selected talented people, it is important to be able to retain those that are of greater value to the organization. HRM research has provided substantial evidence in support of this argument showing that an organization's ability to attract and retain essential employees is positively related to its financial performance (e.g., Becker and Huselid 1992; Shawn et al. 2005). Secondly, the development of high quality products and services that meet the needs of customers has traditionally been found a key driver of financial success (e.g., Zeithaml, 2000; Lynn, 1983). Thirdly, customerrelated performance has also been suggested as a leading contributor to financial returns. Specifically, customer satisfaction and loyalty have been found to lead to market share growth, which is in turn related to firm financial performance (Choi and Eboch 1998; Ou et al. 2010; Yeung 2008). Hence, we expect that firm non-financial performance assessed in terms of its ability to attract and retain essential employees, develop high quality products and services, and satisfy its customers would be positively related to firms' financial success. This relationship is simplified and formally stated here as:

\section{H5: Firm non-financial performance positively affects firm financial performance}

The theoretical framework of our research is summarized in Figure 1. 


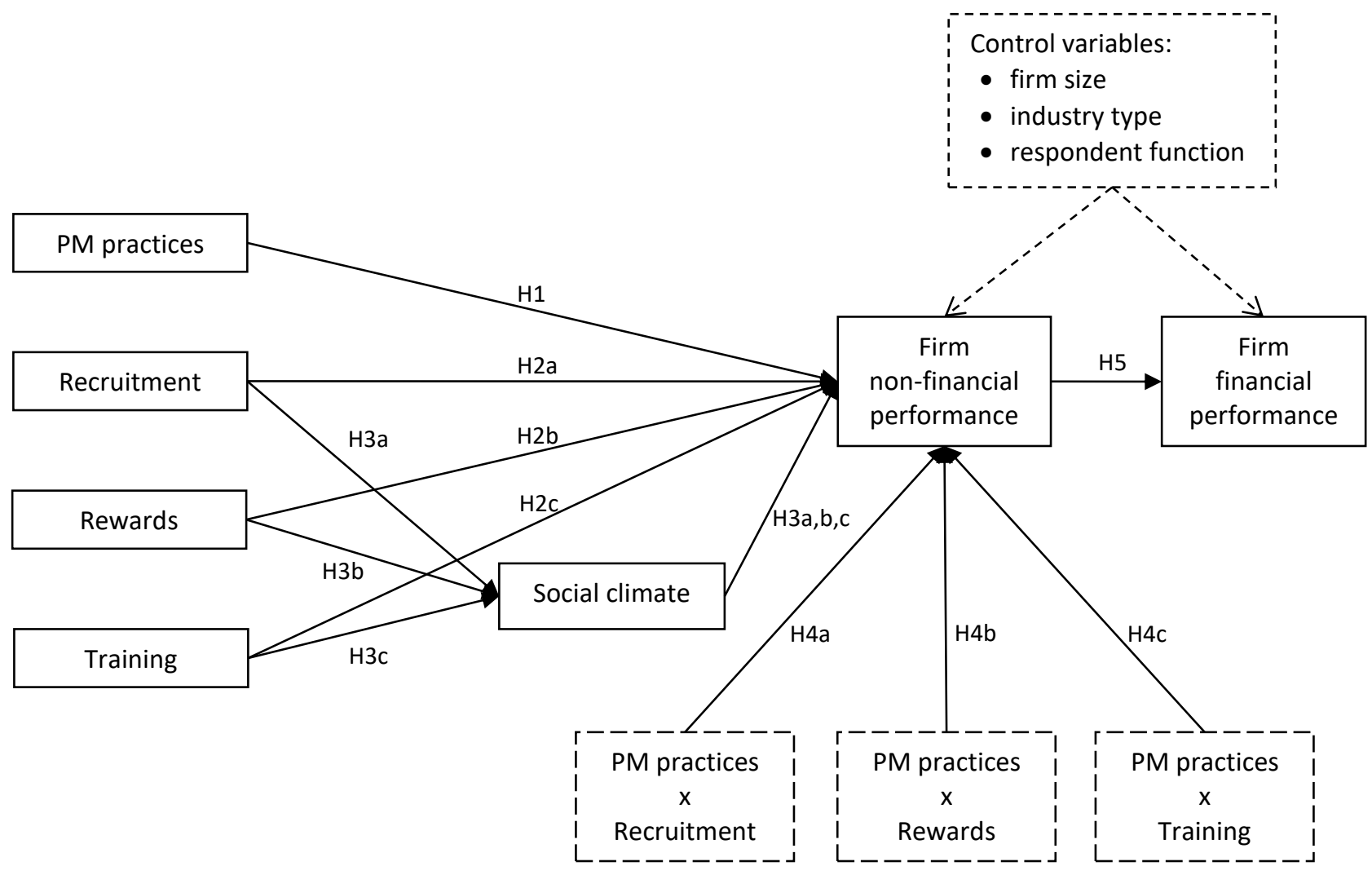

Figure 1. Theoretical model and hypotheses

\section{Data and method}

\subsection{Sample and data gathering process}

To test the proposed hypotheses, data were collected through a structured questionnaire. The target population consisted of 1,200 UK based firms in the range of thirteen different primary UK SIC codes. The questionnaire was sent to the members of the top management team. Before starting our survey, we piloted our questionnaire with a reduced set of respondents, including scholars and HR managers attending our university executive education courses. We mailed our questionnaire to the pilot participants and asked them to complete it and review its content for clarity and understandability purposes. In total 25 respondents provided feedback for the questionnaire 
improvement. Based on our pilot, some redundant or ambiguous items were eliminated or modified.

No new items were added.

Table 1. Sample characteristics

\begin{tabular}{|c|c|c|c|c|c|}
\hline $\begin{array}{c}\text { Company size } \\
\text { (FTE) }\end{array}$ & $\mathrm{N}(\%)$ & $\begin{array}{c}\text { Industry } \\
\text { (UK SIC) } \\
\end{array}$ & $\mathrm{N}(\%)$ & $\begin{array}{c}\text { Respondent } \\
\text { functional area }\end{array}$ & $\mathrm{N}(\%)$ \\
\hline Small (1-49) & $54(28)$ & $\begin{array}{l}\text { Real estate, renting and } \\
\text { business administration }\end{array}$ & $54(28)$ & $\mathrm{HR}$ & $119(67)$ \\
\hline Medium (50-249) & $86(45)$ & Manufacturing & $52(27)$ & operations & $17(10)$ \\
\hline Large (250-4999) & $44(23)$ & $\begin{array}{l}\text { Wholesale retail trade, } \\
\text { repair of motor vehicles, } \\
\text { motorcycle }\end{array}$ & $26(14)$ & Other & $15(8)$ \\
\hline \multirow[t]{9}{*}{ Very large $(>5000)$} & $7(4)$ & Construction & $18(9)$ & Strategy & $9(5)$ \\
\hline & & $\begin{array}{l}\text { Other community, social } \\
\text { and personal service }\end{array}$ & $13(7)$ & Finance/Accounting & $7(4)$ \\
\hline & & Financial intermediation & $8(4)$ & Marketing and sales & $6(3)$ \\
\hline & & Education & $6(3)$ & Admin & $5(3)$ \\
\hline & & $\begin{array}{l}\text { Transport, storage and } \\
\text { communication }\end{array}$ & $4(2)$ & & \\
\hline & & Health and social work & $4(2)$ & & \\
\hline & & Hotels and restaurants & $3(2)$ & & \\
\hline & & $\begin{array}{l}\text { Agriculture, hunting and } \\
\text { forestry }\end{array}$ & $1(1)$ & & \\
\hline & & $\begin{array}{l}\text { Electricity, gas and water } \\
\text { supply }\end{array}$ & $1(1)$ & & \\
\hline Total & $191(100)$ & Total & $190(100)$ & Total & $178(100)$ \\
\hline
\end{tabular}

The survey implementation followed four steps: pre-notification, initial mailing, first follow-up, and second follow-up. To generate early interest, the first step was to invite respondents through an introductory letter, phone call or e-mail. Then the questionnaire was sent via e-mail or post. The first follow-up consisted of a postcard or an e-mail reminder sent to every respondent, while the second follow-up was a phone call and a replacement questionnaire sent to those who had not answered. A total of 192 firms participated in the survey, giving a response rate of $16 \%$, which is similar to the 15-25\% range reported in recent studies (Baines and Langfield-Smith 2003; Lee et al. 2001). Most of 
the companies were medium-sized (45\%), $23 \%$ were large companies, while $28 \%$ were small organizations. Most respondents were from the HR function (67\%), followed by operations (10\%) and strategy (5\%) departments. The sample statistics are listed in Table 1.

\subsection{Measures}

As detailed below, measures were drawn from existing instruments derived from a literature review in the areas of interest across PM and HRM. All measures used a seven-point Likert scale (1= "strongly disagree" and 7= "strongly agree"). The questionnaire was divided into sections examining PM practices, HRM practices, organizational social climate, and firm performance.

Performance management practices. As noted earlier, the literature generally includes as key PM practices the selection of goals, the use of performance measures and targets, as well as the periodic review and evaluation of measured performance (Bititci et al. 1997; Buckingham and Coffman 1999; Ferreira and Otley 2009; Lebas et al. 1995; Otley 1999). Therefore, based on this literature we developed a five-item scale given in the Appendix. The measurement model resulted in one factor with high reliability as shown in Tables 2 and 3.

Commitment-based HRM practices. These practices were conceptually introduced by Arthur's (1992) research and for a number of years the particular practices considered commitment-based varied across studies. However, as suggested by Collins and Smith (2006) most researchers now agree that there are three key sets of practices associated with how organisations 'recruit and select', 'reward' and 'train and develop' their people that create a high commitment-based environment. Thus, we measure commitment-based HRM practices using Collins and Smith's (2006) scales given in the Appendix. The measurement model resulted in three factors with high reliability as presented in Tables 2 and 3. 
Social climate. We measure social climate for trust, cooperation and knowledge sharing using four items extracted from the work of Collins and Smith (2006), Mayer et al. (1995) and Tsui et al. (1997). These items are presented in the Appendix. Our social climate scale demonstrated high reliability and all its items loaded up into one single factor as shown in Tables 2 and 3.

Firm non-financial performance. The measure for firm non-financial performance was assessed by adapting a seven-point Likert scale developed by Delaney and Huselid (1996) and adopted in previous PM and OM studies (Chenhall 2005; Vereecke and Muylle 2006; Villena et al. 2011). The five-item scale asked respondents to compare the performance of their company to that of their competitors over the last three years in terms of quality of products and services, development of new products or services, attraction and retention of essential employees and customer satisfaction.

Firm financial performance. A perceptual measure adapted from Delaney and Huselid (1996) was used to assess firm financial performance. This four-item measure asked respondents to compare, on a seven-point Likert scale, the performance of their company to that of competitors over the last 3 years in terms of turnover, profitability, growth in sales and market share. Additionally, an external validity check was conducted for the financial performance measure. For each company, data on Return on Assets, Turnover and Profit Margin were extracted from the FAME database (1) for the financial year that preceded the administration of the survey. Two of these relative measures of financial performance (ROA and Turnover) were significantly correlated with aggregated measures of subjective performance as rated by senior managers $(r=.21, p<.05$ and $r=.24, p<.05$ respectively), lending strong external validity to the subjective financial performance measure.

Control variables. Previous studies suggested that specific contingencies such as organizational size and industry type may have an effect on our endogenous variable (e.g., Huselid et al. 1997; Malina and Selto 2001). Therefore, the following control variables were included in our model: 
organisational size (natural logarithm of number of employees), industry sector (UK SIC code), manufacturing vs. service (a dummy variable coded 1 for manufacturing and 0 for service). Additionally, since most of the respondents were from the HR function, we included the function of the respondent as a control variable (HR, operations, strategy, finance, marketing, sales, ICT - all measured as dummies).

\subsection{Analytical procedure}

Due to the fact that data were collected from individual respondents in a cross-sectional study, the potential for common method variance (CMV) was a concern (Spector, 2006). Consequently, the external validity of the financial performance measure was checked, as highlighted in the previous section. CMV was assessed after the data were collected using Harman's one-factor test (Podsakoff and Organ 1986). In this test, all the principal constructs are entered into a principal components factor analysis. Evidence of common method bias exists when a single factor emerges from the analysis or when one general factor accounts for the majority of the covariance in the interdependent and dependent variables (Pavlou and Gefen 2005). The fact that each of the principal constructs explained roughly equal variance suggests the data did not indicate substantial common method bias.

The proposed model was tested using the Partial Least Squares approach for structural equations modelling (PLS-SEM) (Wold 1985). PLS-SEM has been employed in numerous OM studies (i.e., Jeffers 2009; Braunscheidel and Suresh 2009; Rosenzweig 2009), as well as in the marketing field (i.e., Cotte and Wood 2004; Anderson and Swaminathan 2011) and in information systems research (Liang et al. 2007; Pavlou and Gefen 2005). PLS-SEM is more appropriate than LISREL when models are complex and there is low theoretical information on the relationships among the constructs (Fornell and Bookstein 1982). PLS-SEM has also been shown to provide higher statistical power than 
covariance-based SEM(e.g. LISREL) when dealing with samples of small or moderate size (Reinartz et al. 2009). Moreover, PLS-SEM does not make assumptions about data distributions to estimate model parameters, observation independence, or variable metrics (Bass et al. 2003). PLS-SEM generates estimates of standardized regression coefficients (beta values) for the model's paths, which

are then used to measure relationships among latent variables. PLS-SEM also generates factor loadings for measurement items, which are interpretable similarly to loadings generated by principal component factor analysis. Therefore PLS-SEM was used in order to effectively manage the high number of variables in the model in relation to the moderate sample size, and the low theoretical support in the identification of the causal relations among the model constructs. This study employed the SmartPLS software version 2.0 (Ringle et al. 2005). To assess the statistical significance of the path coefficients, which are standardized betas, a bootstrap re-sampling procedure (500 sub-samples were randomly generated) was performed (Chin 1998). Following Hulland (1999) the model was analyzed in two steps: first, the measurement model was assessed and the reliability, convergent and discriminant validity of the model constructs were evaluated; secondly, the structural model was evaluated by examining the size and significance of the path coefficients and the $\mathrm{R}^{2}$ values of the dependent variables.

\section{Results}

\subsection{Measurement model}

The Cronbach's alpha, the composite reliability and the average variance extracted (AVE) were calculated to assess the reliability of the constructs. All these coefficients were higher than the recommended thresholds (i.e. Cronbach alpha >0.60, composite reliability > 0.70, and AVE >0.50) 
thus supporting the reliability of all the measures adopted (Hair et al., 2010, 2014; Nunally and Bernstein, 1994). The descriptive statistics and reliability coefficients are provided in Table 2.

Table 2. Descriptive statistics and reliability coefficients

\begin{tabular}{ccccccc}
\hline Construct & $\begin{array}{c}\text { No. of } \\
\text { items }\end{array}$ & Mean & SD & $\begin{array}{c}\text { Cronbach } \\
\text { alpha }\end{array}$ & $\begin{array}{c}\text { Composite } \\
\text { Reliability }\end{array}$ & AVE \\
\hline Financial perf & 3 & 5.121 & 1.283 & 0.810 & 0.887 & 0.724 \\
Non-financial perf. & 4 & 5.569 & 0.864 & 0.808 & 0.874 & 0.634 \\
PM practices & 5 & 5.659 & 1.043 & 0.889 & 0.919 & 0.693 \\
Recruitment & 3 & 5.862 & 1.053 & 0.609 & 0.787 & 0.556 \\
Rewards & 2 & 4.325 & 1.500 & 0.567 & 0.822 & 0.697 \\
Training & 3 & 4.431 & 1.391 & 0.664 & 0.810 & 0.591 \\
Social climate & 5 & 5.169 & 1.234 & 0.903 & 0.939 & 0.837 \\
\hline
\end{tabular}

The convergent validity of the scales was supported, with loadings higher than 0.60 and highly statistically significant $(\mathrm{p}<0.001)$. Moreover, an analysis of factor loadings (see Table 3 ) shows that indicators loaded much higher on their hypothesized factor than on other factors (own loadings are higher than cross-loadings).

Table 3. Factor loadings

\begin{tabular}{cccccccc}
\hline & $\begin{array}{c}\text { Financial } \\
\text { perf. }\end{array}$ & $\begin{array}{c}\text { Non- } \\
\text { financial } \\
\text { perf. }\end{array}$ & $\begin{array}{c}\text { PM } \\
\text { practices }\end{array}$ & Recruitment & Rewards & Training & $\begin{array}{c}\text { Social } \\
\text { climate }\end{array}$ \\
\hline FP1 & $\mathbf{0 . 8 2 6}$ & 0.379 & 0.265 & 0.118 & 0.063 & 0.071 & 0.225 \\
FP2 & $\mathbf{0 . 8 9 6}$ & 0.434 & 0.207 & 0.067 & 0.151 & 0.021 & 0.132 \\
FP3 & $\mathbf{0 . 8 2 9}$ & 0.339 & 0.163 & -0.001 & 0.033 & 0.005 & 0.084 \\
NFP1 & 0.420 & $\mathbf{0 . 7 5 2}$ & 0.377 & 0.257 & 0.240 & 0.243 & 0.292 \\
NFP2 & 0.401 & $\mathbf{0 . 8 1 4}$ & 0.484 & 0.272 & 0.356 & 0.355 & 0.503 \\
NFP3 & 0.317 & $\mathbf{0 . 8 1 8}$ & 0.591 & 0.363 & 0.387 & 0.356 & 0.478 \\
NFP4 & 0.315 & $\mathbf{0 . 7 9 9}$ & 0.460 & 0.278 & 0.263 & 0.363 & 0.357 \\
PM1 & 0.217 & 0.519 & $\mathbf{0 . 8 6 2}$ & 0.451 & 0.403 & 0.510 & 0.575 \\
PM2 & 0.241 & 0.510 & $\mathbf{0 . 7 7 6}$ & 0.454 & 0.286 & 0.321 & 0.438 \\
PM3 & 0.192 & 0.459 & $\mathbf{0 . 8 3 9}$ & 0.467 & 0.250 & 0.429 & 0.424 \\
PM4 & 0.201 & 0.539 & $\mathbf{0 . 8 4 5}$ & 0.390 & 0.334 & 0.563 & 0.660 \\
PM5 & 0.186 & 0.491 & $\mathbf{0 . 8 3 9}$ & 0.319 & 0.281 & 0.517 & 0.635 \\
RC1 & 0.151 & 0.214 & 0.350 & $\mathbf{0 . 7 3 0}$ & 0.118 & 0.097 & 0.182 \\
RC2 & 0.048 & 0.392 & 0.387 & $\mathbf{0 . 8 7 0}$ & 0.244 & 0.283 & 0.317
\end{tabular}




\begin{tabular}{cccccccc} 
RC3 & -0.018 & 0.161 & 0.405 & $\mathbf{0 . 6 1 5}$ & 0.238 & 0.268 & 0.251 \\
RW1 & 0.127 & 0.356 & 0.314 & 0.158 & $\mathbf{0 . 8 4 8}$ & 0.338 & 0.283 \\
RW2 & 0.041 & 0.307 & 0.314 & 0.304 & $\mathbf{0 . 8 2 2}$ & 0.309 & 0.290 \\
TR1 & 0.050 & 0.407 & 0.527 & 0.184 & 0.290 & $\mathbf{0 . 8 6 8}$ & 0.515 \\
TR2 & -0.018 & 0.175 & 0.275 & 0.297 & 0.222 & $\mathbf{0 . 6 5 8}$ & 0.276 \\
TR3 & 0.036 & 0.321 & 0.447 & 0.269 & 0.381 & $\mathbf{0 . 7 6 5}$ & 0.358 \\
SC1 & 0.239 & 0.564 & 0.630 & 0.321 & 0.345 & 0.471 & $\mathbf{0 . 9 3 4}$ \\
SC2 & 0.144 & 0.469 & 0.608 & 0.304 & 0.305 & 0.492 & $\mathbf{0 . 9 2 7}$ \\
SC3 & 0.080 & 0.381 & 0.572 & 0.325 & 0.287 & 0.468 & $\mathbf{0 . 8 8 4}$ \\
\hline
\end{tabular}

In order to assess discriminant validity of the constructs using the PLS-SEM approach, it is necessary that the square root of each factor's AVE is larger than its correlations with other factors (Chin 1998; Gefen and Straub 2005; Straub et al. 2004). As evident from Table 4, the square root of all the AVEs was larger than all other cross-correlations; therefore, discriminant validity was confirmed.

Table 4. Inter-construct correlation

\begin{tabular}{lccccccc}
\hline & 1 & 2 & 3 & 4 & 5 & 6 & 7 \\
\hline 1.Financial perf. & 0.851 & & & & & & \\
2.Non-financial & & & & & & & \\
perf. & 0.455 & 0.796 & & & & & \\
3.PM practices & 0.250 & 0.607 & 0.833 & & & & \\
4.Recruitment & 0.075 & 0.370 & 0.500 & 0.746 & & & \\
5.Rewards & 0.103 & 0.398 & 0.376 & 0.274 & 0.835 & & \\
6.Training & 0.038 & 0.416 & 0.565 & 0.301 & 0.387 & 0.769 & \\
7.Social climate & 0.174 & 0.521 & 0.660 & 0.345 & 0.343 & 0.521 & 0.915 \\
\hline
\end{tabular}

$\mathrm{N}=192$. On the diagonal the square root of the AVE

\subsection{Structural model}

Figure 2 and Table 5 contain the standardized PLS-SEM path coefficients and t-values. The control variables used in this study do not show significant relations and are therefore not reported. 


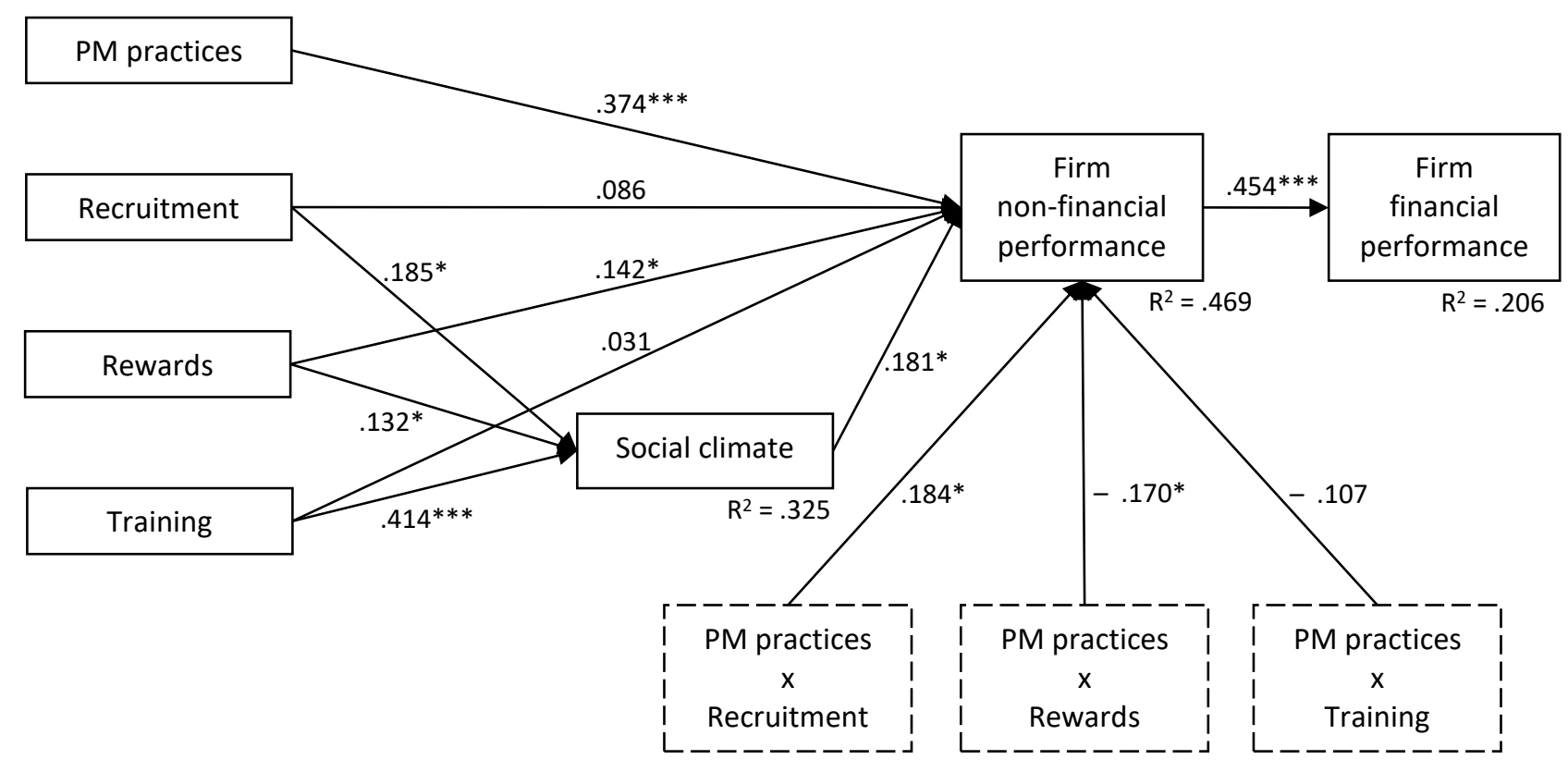

Figure 2. Results of the structural model

Table 5. Path coefficients and t-values

\begin{tabular}{llcl}
\hline Hypothesis & Description of path & Path coefficient & t-value \\
\hline H1 & PM practices -> Non-financial performance & 0.374 & $4.457 * * *$ \\
H2a & Recruitment -> Non-financial performance & 0.086 & 1.524 \\
H3a & Recruitment -> Social climate & 0.185 & $2.518^{*}$ \\
H2b & Rewards -> Non-financial performance & 0.142 & $2.231^{*}$ \\
H3b & Rewards -> Social climate & 0.132 & $2.189^{*}$ \\
H2c & Training -> Non-financial performance & 0.031 & 0.686 \\
H3c & Training -> Social climate & 0.414 & $6.281^{* * *}$ \\
H3a,b,c & Social climate -> Non-financial performance & 0.181 & $2.269^{*}$ \\
H5 & Non-financial performance -> Financial performance & 0.454 & $7.228^{* *}$ \\
H4a & PM x Recruitment -> Non-financial performance & 0.184 & $2.313^{*}$ \\
H4b & PM x Rewards -> Non-financial performance & -0.170 & $2.656^{* *}$ \\
H4c & PM x Training -> Non-financial performance & -0.107 & 1.448 \\
\hline
\end{tabular}

Note: $* p<0.05 ; * * p<0.01 ; * * * p<0.001$

The model explains roughly $21 \%$ of the variance in firm financial performance, $47 \%$ of the variance in firm non-financial performance, and $33 \%$ of the variance in social climate. 


\section{Main effects}

Hypotheses 1 and 2 expect PM practices and commitment-based HRM practices to affect firm non-financial performance directly. The results show that PM practices positively and significantly affect firm non-financial performance $(\beta=0.374, \mathrm{p}<0.001$ ), thus providing support for Hypothesis 1. Hypothesis 2 , however, received only partial support. The three commitment-based HRM practices studied were positively related to firm non-financial performance; however, only commitment-based reward practices positively and significantly affect firm non-financial performance $(\beta=0.142, p<$ 0.05), thus supporting Hypothesis $2 \mathrm{~b}$. Commitment-based recruitment and training practices do not significantly affect firm financial performance $(\beta=0.086, p>0.05$ and $\beta=0.031, p>0.05$, respectively); therefore, Hypotheses $2 \mathrm{a}$ and $2 \mathrm{c}$ are not supported.

\section{Mediation effects}

Considering Hypothesis 3, the results of the PLS-SEM analysis show that all three HRM practices positively and significantly affect social climate (recruitment: $\beta=0.185, p<0.05$; rewards: $\beta=0.132$, $\mathrm{p}<0.05$; training: $\beta=0.414, \mathrm{p}<0.001)$ and social climate positively and significantly affects firm non-financial performance $(\beta=0.181, \mathrm{p}<0.05)$. These results provide support for Hypotheses $3 \mathrm{a}, \mathrm{b}$ and $\mathrm{c}$.

In order to test whether organisational social climate mediates the relationship between HRM practices and firm non-financial performance, we also followed the procedure suggested by Preacher and Hayes (2004 and 2008). The bootstrap analysis suggested the mean indirect effects of the three HRM practices on non-financial performance to be positive and significant ( $\mathrm{x} x \mathrm{~b}=0.109$ for recruitment; $\mathrm{a} \times \mathrm{b}=0.108$ for rewards; $\mathrm{a} \times \mathrm{b}=0.258$ for training), with a $95 \%$ confidence interval 
excluding zero (0.022 to 0.213 for recruitment; 0.031 to 0.199 for rewards; 0.171 to 0.353 for training). Therefore these results provide support for the mediating effect of social climate between HRM practices and firm non-financial performance.

\section{Interaction effects}

Hypothesis 4 posits that the interaction between PM and HRM practices will be positively related to firm non-financial performance. Our data show that the results of this interaction are more complex than expected.
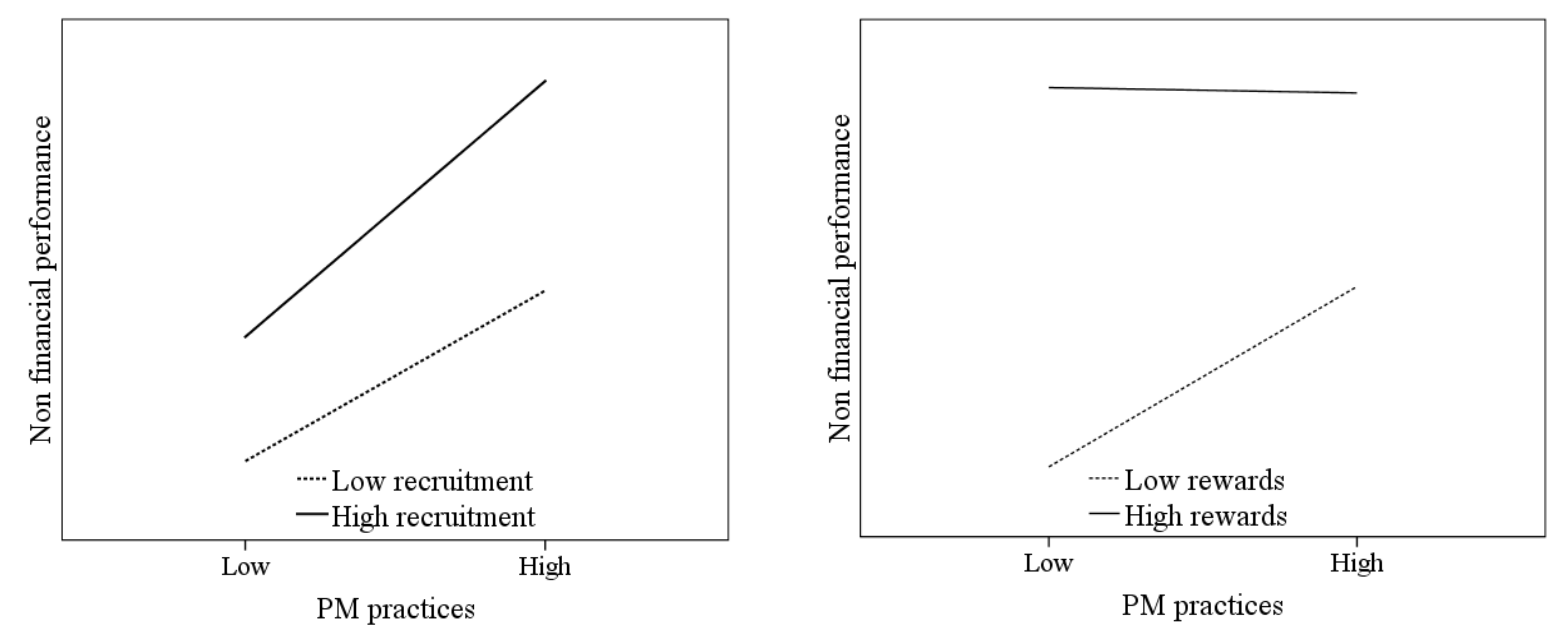

Figure 3. Interaction between PM practices and commitment-based HRM practices

We find that the interaction of PM practices with commitment-based recruitment practices has a positive and significant effect on firm non-financial performance $(\beta=0.184, p<0.05)$. Thus, Hypothesis 4a is supported. Figure 3(a) contains the plot of the interaction effect. The impact of PM practices on performance is stronger when the level of commitment-based recruitment practices is 
also high. Moreover, the slope of the high recruitment regression line is steeper than the slope of the low recruitment line. This suggests that in the environment characterised by high level of PM practices, the interaction effect is even more pronounced, and the strength of commitment-based recruitment practices becomes even more important, as strong recruitment practices have an even greater impact on the relationship between PM practices and non-financial performance than weak recruitment practices do.

The interaction between PM practices and commitment-based reward practices influences nonfinancial performance but not in the way we predicted, as this relationship is negative and significant $(\beta=-0.170, p<0.05)$. Therefore, Hypothesis $4 b$ is not supported. Figure 3(b) contains the plot of the interaction effect. While the effect of high commitment-based reward practices on the relationship between PM and non-financial performance remains essentially unchanged regardless of how strong PM practices are, the effect of low commitment-based rewards changes significantly as the strength of PM practices increases. Finally, the interaction between PM practices and commitment-based training practices seems to influence negatively firm non-financial performance, but this relationship is not statistically significant $(\beta=-0.107, p>0.05)$. Therefore, Hypothesis $4 \mathrm{c}$ is not supported.

Overall, these findings suggest that the interaction of PM practices and two of the three commitment-based HRM practices affects firm non-financial performance; however, these effects are mixed. While high level of commitment-based recruitment practices contributes to strengthening the positive relationship between PM practices and firm non-financial performance, high level of commitment-based reward practices seems to do the opposite in our dataset. Commitment-based training practices display no significant interaction effects.

Firm non-financial and financial performance 
Finally, Hypothesis H5 posits that firm non-financial performance positively affects firm financial performance. The results of this study provide support for this hypothesis as firm non-financial performance positively and significantly influences firm financial performance $(\beta=0.454, p<0.001)$. A summary of the findings is presented in Table 6 .

Table 6. Summary of the results

Relationships discovered

1. PM practices positively affect firm non-financial performance.

2. Commitment-based reward practices positively affect firm non-financial performance.

3. Commitment-based recruitment practices positively affect organizational social climate.

4. Commitment-based reward practices positively affect organizational social climate.

5. Commitment-based training practices positively affect organizational social climate.

6. Organizational social climate positively affects firm non-financial performance.

7. Organizational social climate mediates the effect of all three commitment-based HRM practices on firm non-financial performance.

8. The interaction between PM practices and commitment-based recruitment practices positively affects firm non-financial performance.

9. The interaction between PM practices and commitment-based reward practices negatively affects firm non-financial performance.

\section{Discussion}

As previous research suggests, PM and HRM practices may affect organizational performance on their own. However, building on the ideas of resource orchestration theory (Sirmon et al. 2007, 2011) and the work of Koufteros et al. (2014), we argue that their interaction provides a more complete picture of how resources (in particular, human resources) are orchestrated within organizations and suggest a better explanation of how firm performance is generated. Generally, the results of this study support this argument, as two of the three HRM practices we considered were found to affect the 
relationship between PM and firm non-financial performance. However, the observed effects are quite complex and would therefore benefit from further discussion.

Firstly, the results of this study answer our first research question regarding the independent effects of PM practices and HRM practices on firm performance. Our findings show that PM practices indeed directly affect firm non-financial performance, thus confirming previous studies in this area (Malina and Selto 2001; Ittner et al. 2003). The results also confirm previous research documenting the independent effect of HRM practices on firm performance. However, our study shows that the effect of these practices is partially mediated by the organizational social climate. Specifically, our results show that social climate fully mediates the relationship between recruitment and training practices and firm non-financial performance and partially mediates the effect of rewards on performance. Thus, our findings both support and extend previous studies in this area (Batt, 2002; Bowen and Ostroff 2004; Collins and Clarke 2003; Collins and Smith 2006; Huselid et al. 1997) and suggest that commitment-based HRM practices on their own do not directly contribute to generate firm performance; rather, they foster the development of an organizational social climate based on employees' trust, cooperation, and opportunity to share knowledge that in turn positively influence firm non-financial performance.

As far as the central hypothesis of the study is concerned, our results show that the interaction of PM practices and HRM practices produces mixed effects on firm non-financial performance. Specifically, the interaction between PM practices and commitment-based recruitment practices does have a positive effect on firm non-financial performance, while the interactions of PM practices with the other commitment-based HRM practices studied, for example commitment-based reward practices, may actually have a negative effect. The observed positive effect is consistent with Collins and Smith (2006), who found that employee recruitment and selection practices needed to be focused 
on the internal fit of the employee to the company to engender high commitment. The negative effects, however, need further explanation.

The negative effect may be observed where the HRM practices have been designed on a premise that is different from that of the PM practices. For example, while PM practices are usually aimed at aligning processes across levels and functions and are therefore cross-functional, reward practices may focus on incentivising individual behaviours and hence may be only effective at the functional or departmental level. This discrepancy may contribute to explaining the negative effect of the PMHRM interaction on non-financial performance. The reward practices and the PM system would then negatively affect one another, as they are not built to be mutually supportive in delivering firm nonfinancial performance; rather, they might be based on different aims. Theoretically, this explanation is consistent with the logic of resource orchestration theory, which posits that a positive effect of managerial actions on performance requires not only that such actions be taken, but that they should be synchronized (Koufteros et al. 2014). Empirically, this is very similar to the results obtained by Leffakis and Dwyer (2014), who studied the joint effect of HRM systems and mass customisation practices on performance and found that this effect was negative when the logic of the HRM systems contradicted that of the mass customisation approach.

In our study, commitment-based reward practices were predominantly measured in terms of the level of employees' salary and in terms of perceived equity. It is often the case that managers prone to using common PM practices (e.g., high reliance on performance measures and targets) are also inclined to use incentive pay practices, which are considered to be transaction-based HRM practices rather than commitment-based practices (Ittner and Larcker, 2003). Transaction-based reward practices emphasise individual short-term exchange relationships, negatively affecting mutual trust, collaboration and knowledge sharing, which in turn may negatively affect performance (Tsui et al., 
1995). Therefore, it could happen that a high reliance on PM practices may be more likely to interact with (or indeed lead to) the use of transactional-based reward practices that are in conflict with HRM practices that aim to generate a high commitment environment. The co-existence of conflicting HRM practices within organisations may, in turn, have a negative effect on performance, which could explain our results. Unsurprisingly, having conflicting practices within an organisation appears to be detrimental for performance. Therefore, aligning the PM system and the HRM system seems to be essential if the most is to be made from the investment in these two sets of practices.

In general, viewing the results of this study through the lens of resource orchestration theory highlighted the importance of focusing not only on individual practices but also on their interaction. In doing this, it made a step towards explaining the joint effect of HRM and PM practices on firm performance.

Finally, this study was also able to demonstrate a strong and highly significant relationship between the non-financial and the financial measures of organizational performance - something that often eluded researchers in the past (e.g., Ittner et al. 2003). The strength of this relationship made it possible for this study to trace with confidence the effects of organizational practices and their interaction to firm financial performance.

\section{Conclusions}

The aim of this study was to determine if PM practices and commitment-based HRM practices have an effect on firm performance in their own right, and if the interaction of those two sets of practices have an effect on firm performance. Overall, the results show that PM practices and HRM practices have independent effects on firm non-financial performance, with the effect of HRM practices being mediated by the an organizational social climate for trust, collaboration and 
knowledge sharing. The findings show that the interaction between recruitment practices and PM practices is positively related to firm non-financial and ultimately financial performance. However, the interaction of PM with other commitment-based HRM practices has a negative effect on performance, possibly due to the misalignment between PM and HRM.

This study is important for several reasons. Firstly, it responded to multiple calls in prior research for investigating the role of HRM in supporting PM efforts. While earlier work noted the seeming importance of HRM for the success of PM initiatives, these observations remained largely speculative. This study, however, built on the resource orchestration theory to suggest that managers might indeed use both sets of practices in managing the firm's performance and was subsequently able to demonstrate empirically the presence of the interaction effect between PM practices and two of the three commitment-based HRM practices. In so doing, this study provided some support to the argument that PM does indeed need HRM in order to generate organizational performance. Secondly, the study is based on a robust model, which made it possible to observe the effect of PM and HRM practices and their interaction on both non-financial and financial performance. Finally, the model developed in this study made it possible to surface many nuances in the examined relationships, such as the mediation effect of social climate and the complex nature of the effect of PM-HRM interaction on firm performance.

There are, however, some limitations. Firstly, although our sample was quite large, we had only one respondent per organization. Consequently, we could not triangulate our data by means of intraclass correlation or other measures (e.g., $\mathrm{R}_{\mathrm{wg}}$ ) that would allow us to assess the inter-rater agreement from multiple respondents and increase the validity of our findings. Secondly, the fact that all firms in the sample were based in the UK may limit the opportunity to extend our findings to other geographical areas, especially to those that operate in a significantly different business environment 
(e.g., China or Far East). Finally, the cross-sectional nature of the study assumes that the PM and HRM practices studied are stable across firms, industries, and over time (Bowen and Wiersema, 1999). Yet, these practices may have clear firm-, industry- and time-specific components which may be influencing our results, which means that any claims about the causality of the found relationships must remain tentative - a common issue with studies of this kind. Future studies could employ longitudinal datasets, where independent and dependent variables are collected using time lags that can better control for causality in the hypothesized relationship among model constructs.

The relationships explored in this study suggest several avenues for future research. Firstly, it remains to be seen whether commitment orientation in HRM practices is indeed the factor that determines the sign of their interaction with PM practices. In other words, can HRM practices that are not in Collins and Smith's (2006) definition strictly commitment-based also support PM initiatives in producing an effect on performance? Secondly, the alignment between PM and HRM initiatives as a determinant of their joint effect on organizational performance needs to be investigated further for instance, which dimensions of these practices overlap and what is the nature of the alignment that generates their joint effect on performance? Finally, a firm's experience with PM and HRM practices may also play a role in the relationship we observed. Therefore, future studies may examine the moderating role of experience with PM and HRM practices in the relationship between PM and firm performance or perhaps assess a three-way interaction effect of PM practices, HRM practices, and the experience with using them on firm performance.

\section{Notes}

1. FAME is a database that contains published financial information on companies in the UK and Ireland taken from statutory returns. It has information on 3.4 million companies, 2.6 million of which 
are in a detailed format, so it includes not only information on publicly quoted companies but also on private companies as well. 


\section{References}

Amabile, T. M. \& Kramer, S. J. 2011. "The power of small wins.” Harvard Business Review, 89 (5), 70-80.

Anderson, R.E. and S. Swaminathan. 2011. "Customer satisfaction and loyalty in e-markets: a PLS path modeling approach.” Journal of Marketing Theory and Practice 19(2), 221-234.

Arthur, J. 1992. "The Link Between Business Strategy and Industrial Relations Systems in American Steel Minimills." Industrial and Labor Relations Review, 45(4), 488-506.

Ashkanasy, N. M., C. P. M. Wilderom and M.F. Peterson. 2000. "Introduction.” In Ashkanasy, N., C. P. M., Wilderom, and M. F. Peterson, eds. Handbook of organizational culture and climate. Thousand Oaks, CA: Sage.

Askim, J. 2004. "Performance Management and Organizational Intelligence: Adapting the Balanced Scorecard in Larvik Municipality.” International Public Management Journal 73, 415-438.

Baines, A., and K. Langfield-Smith. 2003. "Antecedents to management accounting change: a structural equation approach.” Accounting, Organizations and Society 287-8, 675-698.

Barney, J. 2001 "Resource-based theories of competitive advantage: A ten-year retrospective on the resource-based view.” Journal of Management 27, 643-650.

Baron, R.M. and D.A. Kenny. 1986. "The Moderator-Mediator Variable Distinction in Social Psychological Research: conceptual, strategic, and statistical considerations." Journal of Personality and Social Psychology 516, 1173-1182.

Bass, B.M., B.J. Avolio, D.I. Jung and Y. Berson. 2003. "Predicting Unit Performance by Assessing Transformational and Transactional Leadership.” Journal of Applied Psychology 88(2), 207218. 
Batt, R. 2002. "Managing customer services: Human resource practices, quit rates, and sales growth." Academy of Management Journal 45, 587-597.

Becker, B.E. and M.A. Huselid. 1992. "Direct estimates of SD and the implications for utility analysis." Journal of Applied Psychology 77, 227-233.

Bititci, U., F. Ackermann, A. Ates, J.D. Davies, S. Gibb, J. MacBryde, D. Mackay et al. 2011. "Managerial processes: an operations management perspective towards dynamic capabilities." Production Planning \& Control 22(2), 157-173.

Bititci, U.F., Carrie, A.S. and McDevitt, L. 1997. "Integrated performance measurement systems: a development guide." International Journal of Operations \& Production Management 17(5), $522-534$.

Bititci, U., S.U.O. Firat and P. Garengo. 2013. "How to compare performances of firms operating in different sectors?" Production Planning \& Control 24(12), 1032-1049.

Boudreau, J., W. Hopp, J.O. McClain and L.J. Thomas. 2003. “On the Interface between Operations and Human Resources Management" Manufacturing \& Service Operations Management 5(3), 179-202.

Bourne, M. 2005. "Researching performance measurement system implementation: the dynamics of success and failure.” Production Planning \& Control 16(2), 101-113.

Bourne, M. and P.A. Bourne. 2011. The Handbook of Corporate Performance Management. London: Wiley.

Bourne, M., A. Neely, J. Mills and K. Platts. 2003. "Why Some Performance Measurement Initiatives Fail: Lessons From the Change Management Literature.” International Journal of Business Performance Management 5(2/3), 245. 
Bourne, M., A. Pavlov, M. Franco-Santos, L. Lucianetti and M. Mura. 2013. "Generating organizational performance: The contributing effects of performance measurement and human resource management practices." International Journal of Operations \& Production Management 33(11/12), 1599-1622.

Bowen, D. E. and C. Ostroff. 2004. "Understanding HRM-firm performance linkages: The role of the 'strength' of the HRM system.” Academy of Management Review 29, 203-221.

Bowen, H. P. and Wiersema, M. F. 1999. "Matching method to paradigm in strategy research: Limitations of cross-sectional analysis and some methodological alternatives." Strategic Management Journal 20, 625-636.

Braam, G.J.M., and E.J. Nijssen. 2004. "Performance Effects of Using the Balanced Scorecard: a Note on the Dutch Experience.” Long Range Planning 37(4), 335-349.

Braunscheidel, M.J. and N.C. Suresh. 2009. "The organizational antecedents of a firms supply chain agility for risk mitigation and response.” Journal of Operations Management 27, 119-140.

Buckingham, M. and C. Coffman. 1999. First break all the rules: what the world's greatest managers do differently. London: Simon \& Schuster.

Busby, J. and A. Williamson. 2000. "The appropriate use of performance measurement in nonproduction activity: The case of engineering design." International Journal of Operations and Production Management 20(3), 336-358.

Chenhall, R.H. 2005. "Integrative strategic performance measurement systems, strategic alignment of manufacturing learning and strategic outcomes: an exploratory study." Accounting Organizations and Society 30, 395-422.

Chin, W.W., 1998. "Commentary: Issues and opinion on structural equation modeling." MIS Quarterly 201, 7-16. 
Choi, T.Y., and K. Eboch 1998. "The TQM paradox: relations among TQM practices, plant performance, and customer satisfaction.” Journal of Operations Management 17, 59-75.

Collins, C. J. and K.D. Clark. 2003. "Strategic human resource practices, top management team social networks, and firm performance: The role of human resource practices in creating organizational competitive advantage.” Academy of Management Journal 46, 740-751.

Collins, J.C. and K.G. Smith. 2006. "Knowledge Exchange and Combination: The Role of Human Resource Practices in the Performance of High-Technology Firms.” Academy of Management Journal 49(3), 544-560.

Cotte, J. and S.L. Wood. 2004. "Families and innovative consumer behavior: a triadic analysis of sibling and parental influence.” Journal of Consumer Research 31, 78-86.

Davila, A. 2000. “An Empirical Study on the Drivers of Management Control Systems Design in New Product Development.” Accounting, Organizations and Society 25(4-5), 383-409

Davis, S. and T. Albright. 2004. "An Investigation of the Effect of Balanced Scorecard Implementation on Financial Performance.” Management Accounting Research 15(2), 135153.

De Geuser, F., S. Mooraj, and D. Oyon. 2009. "Does the Balanced Scorecard Add Value? Empirical Evidence on its Effect on Performance.” European Accounting Review 18(1), 93-122.

de Leeuw, S. and J.P. van de Berg. 2011. "Improving operational performance by influencing shopfloor behavior via performance management practices." Journal of Operations Management 29, 224-235.

De Toni, A. and S. Tonchia. 2001. "Performance Measurement Systems. Models, characteristics and measures." International Journal of Operations and Production Management. 21(1/2), 46-70. 
DeBusk, G.K. and A.D. Crabtree. 2006. "Does the Balanced Scorecard Improve Performance?" Management Accounting Quarterly 8(1), 44-48.

Delaney, J.T., and M.A. Huselid. 1996. "The impact of human resource management practices on perception of organizational performance." Academy of Management Journal 394, 949-969.

Evans, J.R., 2004. “An exploratory study of performance measurement systems and relationships with performance results.” Journal of Operations Management 22(3), 219-232.

Ferreira, A. and Otley, D. 2009. "The design and use of performance management systems: An extended framework for analysis.” Management Accounting Research, 20(4), 263-282.

Folan, P. and J. Browne. 2005. "Development of an extended enterprise performance measurement system." Production Planning \& Control 16(6), 531-544.

Fornell, C. and F.L. Bookstein. 1982. "Two structural equation models: LISREL and PLS applied to consumer exit-voice theory.” Journal of Marketing Research 19(4), 440-452.

Franco-Santos, M., L. Lucianetti and M. Bourne. 2012. “Contemporary performance measurement systems: A review of their consequences and a framework for research." Management Accounting Research 23(2), 79-119.

Gefen, D. and D.W. Straub. 2005. "A practical guide to factorial validity using PLS-graph: tutorial and annotated example.” Communications Association of Information Systems 16(5), 91-109.

Goodridge, I., 1986. "New concepts in manufacturing.” Management Services 30, 14-17.

Griffith, R., and A. Neely. 2009. "Performance Pay and Managerial Experience in Multitask Teams: Evidence From Within a Firm.” Journal of Labor Economics 27(1), 49-82.

Hall, M. 2008. "The effect of comprehensive performance measurement systems on role clarity, psychological empowerment and managerial performance.” Accounting, Organizations and Society 33, 141-163. 
Hair, J.F., Black, W.C., Babin, B.J. and R.E. Anderson. 2009. Multivariate Data Analysis. $7^{\text {th }}$ Edition. Prentice Hall.

Hair, J.F., Hult, G.T.M., Ringle, C.M. and M. Sarstedt. 2014. A Primer on Partial Least Squares Structural Equation Modeling (PLS-SEM). Sage.

Henri, J.F. 2006. "Management control systems and strategy: A resource-based perspective." Accounting, Organizations and Society 31, 529-558.

Hertzberg, F., B. Mausner and B.B. Snyderman. 1959. The Motivation to Work. New York: Wiley. Hofstede, G. 1978. “The Poverty of Management Control Philosophy.” Academy of Management Review 33, 450-461.

Hoque, Z. 2004. "A contingency model of the association between strategy. environmental uncertainty and performance measurement: impact on organizational performance." International Business Review 13(4), 485-502.

Hoque, Z. and W. James. 2000. "Linking Balanced Scorecard Measures to Size and Market Factors: Impact on Organizational Performance.” Journal of Management Accounting Research 12, 117.

Hulland, J. 1999. "Use of Partial Least Squares PLS in Strategic Management Research: a review of four recent studies.” Strategic Management Journal 202, 195-204.

Huselid, M.A., S.E. Jackson, and R.S. Schuler 1997. "Technical and strategic human resource management effectiveness as determinants of firm performance." Academy of Management Journal 401, 171-188.

Hyvonen, J. 2007. "Strategy, Performance Measurement Techniques and Information Technology of the Firm and Their Links to Organizational Performance.” Management Accounting Research 18(3), 343-366. 
Ittner, C.D. and D.F. Larcker. 1998. “Are Nonfinancial Measures Leading Indicators of Financial Performance? An Analysis of Customer Satisfaction.” Journal of Accounting Research 36, 135.

Ittner, C.D., D.F. Larcker, and R. Randall. 2003. "Performance Implications of Strategic Performance Measurement in Financial Services Firms.” Accounting, Organizations and Society 28(7/8), $715-741$.

Jeffers, P.L., 2009. "Embracing Sustainability: information technology and the strategic leveraging of operations in third-party logistics." International Journal of Operations and Production Management 303, 260-287.

Johnston, R., and S. Michel. 2008. "Three outcomes of service recovery: Customer recovery, process recovery and employee recovery." International Journal of Operations and Production Management 28(1), 79-99.

Kaydos, W., 1999. Operational Performance Measurement: Increasing Total Productivity. St. Lucie Press, Boca Raton, FL.

Kaplan, R.S. and D.P. Norton. 1992. "The balanced scorecard - measures that drive performance." Harvard Business Review Jan/Feb, 71 - 79.

Kaplan, R. S. and D.P. Norton. 2000. "Having trouble with your strategy? Then map it." Harvard Business Review Sept-Oct, 167-176.

Kennerley, M. and A. Neely. 2003. "Measuring performance in a changing business environment." International Journal of Operations and Production Management 23(2), 213-229.

Kinnie, N.J. and R.V.W. Staughton. 1991. "Implementing Manufacturing Strategy: The Human Resource Management Contribution.” International Journal of Operations and Production Management 11(9), $24-40$. 
Koufteros, X., A. Verghese and L. Lucianetti. 2014. "The effect of performance measurement systems on firm performance: A cross-sectional and a longitudinal study." Journal of Operations Management 32, 313-336.

Lebas, M. 1995. "Performance measurement and performance management." International Journal of Production Economics, 41(1-3), 23-35.

Lee, C., K. Lee, and J.M. Pennings. 2001. "Internal capabilities, external networks, and performance: a study on technology-based ventures.” Strategic Management Journal 22, 615-640.

Leffakis, Z.M. and D.J. Dwyer. 2014. "The effects of human resource systems on operational performance in mass customisation manufacturing environments." Production Planning \& Control 25(15), 1213-1230.

Liang, H., N. Saraf, Q. Hu, and Y. Xue. 2007. "Assimilation of enterprise systems: The effect of institutional pressures and the mediating role of top management." MIS Quarterly 311, 59-87.

Lingle, J.H. and W.A. Schiemann. 1996. "From Balanced Scorecard to Strategy Gauge: Is Measurement Worth It?" Management Review 85(3), 56-62.

Lynn W., D. R. Chang, and R. D. Buzzell. 1983. "Product Quality, Cost Position, and Business Performance: A Test of Some Key Hypotheses.” Journal of Marketing 47, 26-43

Malina, M.A., and F.H. Selto. 2001. "Communicating and Controlling Strategy: an Empirical Study of the Effectiveness of the Balanced Scorecard." Journal of Management Accounting Research $13,47$.

Mayer, R.C., J.H. Davis, and F.D. Schoorman. 1995. "An integrative model of organizational trust." Academy of Management Review 20, 709-734. 
McClean, E., \& Collins, C. J. 2011. "High-commitment HR practices, employee effort, and firm performance: Investigating the effects of $\mathrm{HR}$ practices across employee groups within professional services firms." Human Resource Management, 50, 341-363.

Nahapiet, J. and S. Goshal. 1998. "Social capital, intellectual capital, and the organizational advantage." Academy of Management Review 23(2), 242-266.

Nudurupati, S. and U. Bititci. 2005. "Implementation and impact of IT-supported performance measurement systems." Production Planning \& Control 16(2), 152-162.

Nunally, J.C. and I.H. Bernstein. 1994. Psychometric theory. New York, McGraw-Hill.

Olve, N., J. Roy, and M. Wetter. 1999. Performance drivers: a practical guide to using the balanced scorecard. Chichester: Wiley.

Otley, D.T. (1999), "Performance management: a framework for management control systems research", Management Accounting Research 10(4), 363-82.

Ou, C.S., F.C. Liu, Y.C. Hung and D.C. Yen. 2010. “A structural model of supply chain management on firm performance.” International Journal of Operations and Production Management 30(5), $526-545$.

Pavlou, P.A. and D. Gefen. 2005. "Psychological Contract Violation in Online Marketplaces: antecedents, consequences and moderating role.” Information System Research 164, 372-399.

Pavlou, P.A. and D. Gefen. 2005. "Building effective online marketplaces with institution-based trust.” Information System Research 15(1), 37-59.

Pavlov, A. and M. Bourne. 2011. "Explaining the effects of performance measurement on performance. An organizational routines perspective." International Journal of Operations and Production Management 31(1), 101-122. 
Podsakoff, P.M., and D. Organ. 1986. "Self-reports in organizational research: problems and prospects." Journal of Management 12(4), 531-544.

Preacher, K.J. and A.F. Hayes 2004. "SPSS and SAS procedures for estimating indirect effects in simple mediation models". Behavioral Research Methods, Instruments, \& Computers 36(4), 717-731.

Preacher, K.J. and A.F. Hayes 2008. "Asymptotic and resampling strategies for assessing and comparing indirect effects in multiple mediator models". Behavioral Research Methods 40(3), 879-891.

Reinartz, W., M. Haenlein, and J. Henseler. 2009. "An empirical comparison of the efficacy of covariance-based and variance-based SEM.” International Journal of Research in Marketing 264, 332-344.

Ringle, C.M., S. Wende, and A. Will. 2005. SmartPLS 2.0 M3 Beta. Hamburg. Germany.

Rosenzweig, E.D. 2009. "A contingent view of e-collaboration and performance in manufacturing." Journal of Operations Management 27, 462-478.

Rousseau, D.M. 1995. Psychological contracts in organizations: Understanding written and unwritten agreements. Thousand Oaks, CA: Sage.

Rucci, A.J., S.P. Kirn, and R.T. Quinn. 1998. "The employee-customer profit chain at Sears." Harvard Business Review Jan/Feb, 82-97.

Schuler, R.S., J.R. Fulkerson, and P.J. Dowling. 1991. "Strategic Performance Measurement and Management in Multinational Corporations.” Human Resource Management 30(3), 365-392.

Scott, T.W. and P. Tiessen. 1999. "Performance Measurement and Managerial Teams.” Accounting, Organizations and Society 24(3), 263-285. 
Shawn, J.D., N. Gupta, and J.E. Delery. 2005. "Alternative conceptualizations of the relationship between voluntary turnover and organizational performance." Academy of Management Journal 48(1), 50-68.

Sila, I. and M. Ebrahimpour. 2005. "Critical linkages among TQM factors and business results." International Journal of Operations and Production Management 25(11), 1123-1155.

Smith, K. G., Collins, C. J., \& Clark, K. D. 2005. "Existing knowledge, knowledge creation capability, and the rate of new product introduction in high-technology firms." Academy of Management Journal, 48, 346-357.

Spector, P.E. 2006. “Method variance in organizational research.” Organizational Research Methods 9, 221-232.

Straub, D., M.C. Boudreau, and D. Gefen. 2004. "Validation guidelines for IS positivist research." Communications Association of Information Systems 14, 380-426.

Tsui, A.S., J.L. Pearce, L.W. Porter, and J.P. Hite. 1995. "Choice of employee-organization relationship: Influence of external and internal organizational factors." in G. R. Ferris, ed. Research in personnel and human resource management. Greenwich. CT: JAI Press.

Vagneur, K and M. Peiperl. 2000. "Reconsidering performance evaluative style." Accounting, Organizations and Society 25, 511-525.

van der Stede, W., C. Chow, and T. Lin. 2006. "Strategy, Choice of Performance Measures, and Performance." Behavioral Research in Accounting 18(1), 185

Vereecke, A. and S. Muylle. 2006. "Performance improvement through supply chain collaboration in Europe." International Journal of Operations and Production Management 26(11), 1176-1198.

Villena, V.H., E. Revilla, and T.Y. Choi. 2011. "The dark side of buyer-supplier relationships: A social capital perspective.” Journal of Operations Management 29(6), 561-576. 
Wol, H. 1985. "Partial Least Squares." in Vol. 6 of Kotz. S and N.L. Johnson, eds. Encyclopedia of Statistical Sciences. New York: Wiley.

Wright, P.M., T.M. Gardner, and L.M. Moynihan. 2003. "The impact of HR practices on the performance of business.” Human Resource Management Journal 13(3), 21-36.

Yeung, A.C.L. 2008. "Strategic supply management, quality initiatives, and organizational performance.” Journal of Operations Management 26(4), 490-502.

Youndt, M.A., S.A. Snell, J.W. Dean, and D.P. Lepak. 1996. "Human resource management, manufacturing strategy, and performance.” Academy of Management Journal 39(4), 836-866.

Zeithaml, V. 2000. "Service quality, profitability, and the economic worth of customers: What we know and what we need to learn." Journal of the Academy of Marketing Science 28(1), 67. 


\section{Appendix. Questionnaire items}

We asked respondents to compare, on a seven-point Likert scale, their company's performance over

the last three years to that of their competitors in terms of:

\begin{tabular}{lll}
\hline Scales & Items & \\
\hline Financial & FP1 & Turnover \\
performance & FP2 & Profitability \\
& FP3 & Market share \\
& FP4 & Growth in sales* \\
\hline Non-financial & NFP1 & Quality of products and services \\
performance & NFP2 & Ability to attract essential employees \\
& NFP3 & Ability to retain essential employees \\
& NFP4 & Satisfaction of customers/clients \\
& NFP5 & Development of new products, services or programs* \\
\hline
\end{tabular}

We asked respondents to indicate, on a seven-point Likert scale, the degree to which they agreed or disagreed with the following statements.

\begin{tabular}{|c|c|c|}
\hline Scales & Items & \\
\hline \multirow{5}{*}{$\begin{array}{l}\text { Performance } \\
\text { management }\end{array}$} & PM1 & People know what is expected of them at work \\
\hline & PM2 & People have the materials and equipment needed to do their job right \\
\hline & PM3 & People have clear targets to achieve \\
\hline & PM4 & People receive regular feedback on their performance \\
\hline & PM5 & People know how their performance at work contributes to the company's goal \\
\hline \multirow[t]{4}{*}{ Recruitment } & $\mathrm{RC} 1$ & We select employees based on an overall fit to the company \\
\hline & $\mathrm{RC} 2$ & $\begin{array}{l}\text { Our selection system focuses on the potential of the candidate to learn and grow with the } \\
\text { company }\end{array}$ \\
\hline & $\mathrm{RC} 3$ & We ensure that all employees are made aware of internal promotion opportunities \\
\hline & $\mathrm{RC} 4$ & Internal candidates are given consideration over external candidates for job openings* \\
\hline \multirow[t]{4}{*}{ Rewards } & RW1 & Salaries for employees are higher than those of our competitors \\
\hline & RW2 & Rewards are designed to ensure equity with peers \\
\hline & RW3 & $\begin{array}{l}\text { Employee bonuses or inventive plans are based primarily on the performance of the } \\
\text { company* }\end{array}$ \\
\hline & RW4 & Shares of stocks are available to all employees through specific plans* \\
\hline \multirow[t]{5}{*}{ Training } & TR1 & We provide training focused on team-building and teamwork skills \\
\hline & TR2 & We use job rotation to expand the skills of employees \\
\hline & TR3 & We have a mentoring system to help develop our employees \\
\hline & TR4 & $\begin{array}{l}\text { We provide multiple career path opportunities for employees to move across functional } \\
\text { areas of the company* }\end{array}$ \\
\hline & TR5 & $\begin{array}{l}\text { We offer an induction programme that introduces employees to the history and objectives } \\
\text { of the company* }\end{array}$ \\
\hline \multirow{4}{*}{$\begin{array}{l}\text { Social } \\
\text { climate }\end{array}$} & $\mathrm{SC} 1$ & There is high level of cooperation between employees and teams in this company \\
\hline & $\mathrm{SC} 2$ & There is high level of knowledge sharing between employees in this company \\
\hline & SC3 & Employees here are willing to sacrifice their self-interests for the benefit of the team \\
\hline & $\mathrm{SC} 4$ & In this company is important to maintain harmony within teams and among employees* \\
\hline
\end{tabular}

* Item dropped after the measurement model validity and reliability tests. 